\title{
Editorial
}

\section{Quaker Belief and Child Psychiatry ${ }^{1}$}

\author{
PHILIP GRAHAM
}

George Fox, the Leicestershire-born founder of the Quaker movement, believed it was his mission to save people from false religion. He was imprisoned many times for interrupting preachers in church and uttering what were regarded as blasphemies. By 1652 , when he was 28 years of age, he had convinced thousands of people of the truth of his views and the Society of Friends was born. Among the early Friends was William Penn who founded the State of Pennsylvania and the Society of Friends has, from its early days, been most numerous in the USA. There have been numerous important schisms in the movement, particularly between those who have espoused evangelical activity and those who have opposed it. The liberal wing of the Quaker movement has predominated in England and has been characterised by tolerance in religious matters, by its tenacity in pacifist belief, and by its activity in philanthropy and social reform. It is not easy to describe very precisely the details of Quaker beliefs, firstly because of the schisms in the movement, but also because, very naturally, Quaker views have changed over the years. Nevertheless there is a core set of beliefs that has remained unchanged.

Links between current views on child development and Quaker belief have previously been helpfully explored by Rutter (1983). In this editorial I shall concentrate on the relevance of Quaker belief for some aspects of child psychopathology.

\section{Goodness and human nature}

The central Quaker belief is that shared with most of the other dissident religious movements of the mid-seventeenth century. This is that God is present in every human being and that consequently goodness that is to be valued is also present in all of us. There are numerous consequences of this

1. This editorial is based on the Mildred Creak Memorial Lecture given on 20 October 1994 at the Annual Residential Meeting of the Child and Adolescent Psychiatry Section of the Royal College of Psychiatrists
Quaker belief in the existence of goodness in every human being.

Goodness is not a subject much discussed by psychiatrists who, very naturally, focus on behaviour that, if viewed from a moral perspective, is much more likely to be negatively evaluated. Nevertheless there are various connections between goodness and child and adolescent psychopathology, some of which I have previously discussed (Graham, 1980). The negative correlation found in younger children between altruism and generosity on the one hand, and antisocial behaviour on the other (Weir \& Duveen, 1981) is one example. It is of interest that in a recent, now widely used modification of the Rutter Behaviour Questionnaire, Goodman (1994) has incorporated questions relating inter alia to sharing behaviour, kindness to animals and considerateness. The possibly pathological need to serve others and discount the self that is so apparent in many teenage girls suffering from anorexia nervosa has often been described. Finally, the consequences of Quaker belief, to which I shall return later, that everyone is of sufficient value to have a right to be heard is surely also a central tenet of much child psychiatric practice in which, especially in family sessions, those who do not speak readily, such as children and fathers who seem to have withdrawn from family life, are particularly encouraged to do so, because what they have to say is valued.

\section{The nature of evil}

Quaker belief is less well developed in relation to the darker side of human nature. Quakers accept the presence of antisocial or bad behaviour with some difficulty because of their emphasis on the goodness that is present in every human being. However they do accept its existence and favour both natural explanations and explanations that involve conflict between, on the one hand, physical and on the other, rational and spiritual aspects of our make-up. Quaker thinkers such as Rufus Jones, writing in the first half of the 20th century, see evil 
as the absence of the good, compounded by error or misjudgement. If the passions of the lower self disturb the rational calculations of the higher self, then error in judgement is bound to occur (Cooper, 1990). Quakers, like child psychiatrists, do not tend to view wrongdoing in morally condemnatory terms. They view those who are clearly behaving in a way that is harmful to others as in need of guidance to help them to choose better paths of conduct.

The views of both Quakers and child psychiatrists in this respect are frequently challenged by the fact that some people, indeed some children, behave in a way that cannot convincingly be described merely as the absence of goodness. "Evil" has been recently considered in relation to general psychiatry by Prins (1994), but the issues appear somewhat different where children and child psychiatrists are concerned.

Over the past four years the nature of evil has received an increasing amount of attention in the press in relation to a number of horrific acts committed by both adults and children. The term was widely used to describe both the behaviour of the boys who murdered James Bulger in November 1993 and the boys themselves. These boys were thought by some to show behaviour that was qualitatively and not just quantitatively different from the ordinary run of behaviour shown by aggressive boys who physically bully and sadistically intimidate other children.

Clinical experience suggests that this usage has ominous implications when employed by a parent about his or her own child. A father, with or without a background of religious belief, may tell you that his 8-year-old son with a conduct disorder was "just born evil". He could tell from the look in this boy's eye from the moment he was born. He was born like his uncle who is now doing time in Brixton Prison. He, the father, has done his best. He has thrashed the living daylights out of the boy, but this has done no good. His son is evil, "and I'm afraid doctor (I'd love to be proved wrong), but I'm afraid doctor, there's nothing you are going to be able to do about it either". This father believes his child is innately evil. As the Bulger case revealed, many members of the public, some senior police officers and some journalists in both the quality and tabloid press, take the view that this is entirely possible, and explanatory of behaviour that is generally regarded as extremely bad.

Evil, like the serpent metaphorically associated with it, is a slippery subject, and one can only begin to pin it down with dictionary definitions. The shorter Oxford dictionary (OED) considers the word in the adjectival sense to have both a strong positive and a weak privative meaning. The adjective in its positive sense is defined as meaning morally depraved, and this sense the OED rather surprisingly and surely incorrectly says is obsolete when applied to persons. In addition, the adjective means "doing or tending to do harm" and "causing discomfort, pain or trouble". In its privative sense, that is in the weak sense in which it refers to the absence of an attribute, "evil" merely means "not good" or "the reverse of good". The OED refers to the substantive form, the noun "evil" as that which contains "evil" qualities, e.g. "any particular thing that causes harm or mischief, physical or moral" and "a wrongdoing, sin or crime".

What most people using the word today mean by the adjective is surely "extremely bad" or "bad in a way that is quantitatively or qualitatively different from and worse than ordinary badness". The attributes of behaviour that lead most of us to use the word of an individual are that his or her behaviour results in serious harm, that the behaviour is gratuitous and apparently without motivation, and that it is inflicted on a person or an animal, who at the time, is weak and defenceless.

The identification of a cause or set of causes for gratuitously cruel behaviour, especially in severe form, raises issues of general importance. For social scientists, including child psychiatrists, the causes of "evil" behaviour are to be sought in natural phenomena, especially the interplay between genetic and environmental factors. Indeed much information has already been obtained on the importance of temperament, brain dysfunction, dysfunctional family relationships, and, perhaps of more specific relevance, the offender's own experience of physical and sexual abuse. There is certainly much we do not understand, but for most child psychiatrists there is only one way to push forward the frontiers of knowledge in this area, and that is by the systematic scientific study of individuals and groups. Such studies might reveal that extreme forms of gratuitously cruel behaviour have specific causes (e.g. specific gene defects or specific early experiences). Alternatively they might reveal that extreme forms of aggressive behaviour are merely a reflection of the presence of extreme forms of the same factors that produce milder aggressive behaviour.

But for many people there is another, more sinister possibility, namely that supernatural forces are required to explain "evil" behaviour. The belief that satanic influences or "forces of evil" exist is by no means confined to fundamentalist sects. For some, these beliefs form part of systematic religious 
faith. For others, natural explanations of evil behaviour are unsatisfactory, and the supernatural is invoked to remedy a deficiency of understanding. Child psychiatrists and other social scientists may have a part to play here in publicising well-founded existing knowledge of the causes of, for example, gratuitously cruel behaviour and the progress that is being made to provide fuller understanding.

There are three main types of information that diminish the need for supernatural explanation. The particular type of behaviour may be partly but clearly explained by prior experiences of the person responsible. A child may have had done to him what he himself has done to another. Or he may have viewed very similar behaviour on television or video. Secondly, there may be a physical or medical explanation for the behaviour. If either of the boys convicted of the murder of James Bulger turns out to have the Fragile $X$ syndrome, a form of epilepsy, or a mental illness such as schizophrenia (all unlikely but not inconceivable), the need for a supernatural explanation is reduced. If, as a result of treatment, psychological or physical, persistent behaviour (that could be regarded as evil) stops - again the appropriateness of a supernatural explanation is called in question. A devil might be removed through exorcism, but devils are hardly likely to be troubled by a course of cognitive behaviour therapy, a small dose of haloperidol or the opportunity to form a trusting relationship with an accepting member of staff of a residential unit.

These are ways in which clinical child psychiatrists and psychologists might exert influence on public opinion concerning the presence of supernatural forces. But there are also ways in which research findings can or might contribute. The concept of variance is relevant here. If, after a multivariate analysis of data collected on the background of children with a particular type of aggression, it can be demonstrated that much of the behaviour can be explained on the basis of such background factors, this leaves less room for the need for alternative explanations. Now it is arguable just to what degree current research findings do explain seriously aggressive behaviour. Clearly we cannot by any means explain all such behaviour and, because of the infinite variety of human behaviour and the complex interaction between genes and environment, it is unlikely we ever will, especially in the individual child. But the proportion of explained variance is rising decade by decade, and that section of the public uncertain about the supernatural needs to know that. The more we can explain, the less there is need for recourse to supernatural explanations that suggest forces exist that are outside our control.

The notion that evil behaviour might be explained entirely by "natural" rather than supernatural causes, requires further clarification. The shorter OED definition, quoted above, makes it clear that in its strong, positive sense, evil involves the contravention of moral standards. But belief in a moral framework does not necessarily entail any particular form of religious or other belief in the supernatural. Morality can emerge from humanism as, for example, defined by Francis Crick, as a set of beliefs that "human problems can and must be faced in terms of human and moral resources without recourse to supernatural authority".

There are therefore at least three frameworks in which cruel behaviour, defined as "evil" can be considered. It can be seen as behaviour that is more or less morally reprehensible, as behaviour requiring a supernatural explanation, possibly, but not necessarily, forming part of a systematic religious belief, or, and it is here that most Quakers and most child psychiatrists are in agreement, as a naturally occurring phenomenon, wholly or partly explicable in natural terms without recourse to moral judgement.

\section{Quakers and violence}

If goodness is present in every human being, it must be wrong to take the life of another person, however apparently evil that person or what he or she stands for may be. The consequent Quaker emphasis on peaceful, non-violent means to resolve conflict is well known.

In the nineteenth century, Quaker beliefs in the non-violent resolution of political and religious conflicts did not entail the prohibition of the use of vigorous physical violence towards children at home or in school (Campbell Stewart, 1953). However Quaker schools were among the first to abandon corporal punishment as a means of discipline. Further, as far as the use of physical punishment by parents in the home is concerned, there is a widespread view among both Quakers and child psychiatrists that the use of positive methods of discipline, and the affection and warmth that a parent is able to show for a disobedient child, are far more important than whether physical punishment is used or not. The use of corporal punishment as a legitimate means whereby parents discipline their children, is now on the political agenda, with an active campaign to introduce legislation to outlaw the practice. Both Quakers and child psychiatrists might regard it as unwise to 
be dogmatic about the need for legislation to prohibit corporal punishment by parents, but the arguments in favour of a public education campaign leading before too long to the sort of legislation that has already been passed in five other countries, is compelling. It is difficult to sustain a view that it really does not matter whether children are hit by their parents. If it is wrong for a man to hit his wife or his partner, it is wrong for a man to hit his son or daughter. If it is impossible to establish a satisfactory threshold for physical punishment why not abolish it? Of course, as is often said, a few mild smacks in the context of a loving relationship do no harm. But one man's mild smack is another man's heavy beating, is another toddler's heavy bruising or broken limb. If we cannot draw a line, why not discourage the practice very firmly altogether?

\section{Other Quaker activities in the child wolfare field}

Another characteristic of the Quaker movement that brings it close to the field of child psychiatry is the activity of the Society of Friends in the field of special education for children and young people with behavioural and emotional problems. Some of the mainstream Quaker schools have made it a policy to provide for children with such difficulties. Quakers have also set up special schools and therapeutic communities for disturbed young people. Some of the most progressive movements in the field of education have come from the Quaker movement. They were among the first to provide co-educational residential education, and the organisation of their schools early on allowed for the voice of students themselves to be heard in schools' councils.

Quakers have also played a major part in the promotion of child welfare, mental health and the treatment of mental illness. Wagner (1987) describes the fortunes of those three great philanthropic Quaker families whose fortunes were all established in the manufacture of chocolatethe Cadburys, the Frys and the Rowntrees. These are all families that have produced social reformers whose work is of interest to child psychiatrists, such as Elizabeth Fry with her campaign for improvement of prisons, and Joseph Rowntree who conducted and published enquiries into the state of the poor. Incidentally, Samuel Tuke, who founded The Retreat, the Quaker mental hospital in York where Mildred Creak, a founding figure in British child psychiatry, worked early in her career, was a member of the Tuke family that was also in chocolate manufacture before being taken over by the Rowntrees. These families founded charitable trusts that continue to support social research, especially in child poverty, to this day.

\section{Conclusion}

We have seen over the last 15 years an increasing development of an individualistic, competitive mode of existence based on a market economy which extends beyond the usual province of the market, i.e. banking, commerce etc. into education, health and the arts. Many are deeply disturbed by this trend. For many of us, our social needs are not met unless we live and work in groups - family groups, work groups, study groups, etc. On the other hand we also know that individual behaviour and responsibility are readily debased when human beings group together. Even in small groups, a powerful group experience may prevent an individual from going against the tide.

How can human groups be formed that allow individual integrity to be maintained? It is here that the form of worship the Quakers have developed is so interesting. They believe that men, women and children, if of sufficient understanding, should communicate directly with God without any human intermediaries. Their acts of worship are therefore not conducted by clergy specially designated for this purpose. Instead, a group of people meet so that individuals can speak if they are so moved but maintain silence if they are not. But this is not the only way in which the value of the individual within a group can be maintained. Experience in participation in seminars, working groups, committees and groups of many other types can also lead to the achievement of individuality within a group experience. This surely has implications for many aspects of our own practice. In family therapy, we should value not only the family group, but the individual voice of each family member, perhaps especially including the children. In group therapy, consultation groups, multidisciplinary groups, research groups - the same principle needs to prevail. Multidisciplinary teams should surely experience a sense of communion and common purpose, and team members should be able to work together in a group while retaining their individual, personal and professional identities. Maybe in our current ways of working we are in danger of losing this ethos; if that is the case, perhaps psychiatrists should take 
greater pains to bear in mind the relevance of Quaker beliefs.

\section{References}

CAMPBELL StEWART, W. A. (1953) Quakers and Education. Oxford: Epworth Press.

Cooper, W. A. (1990) A Living Faith: An Historical Study of Quaker Beliefs. Richmond, Indiana: Friends United Press.

Crick, F. (1968) Quoted in Quakers and Humanists (W. H Thorpe), pp. 27-28. London: Friends Home Service Committee. Goodman, R. (1994) A modified version of the Rutter Parent Questionnaire including extra items on children's strengths: a research note. Journal of Child Psychology and Psychiatry, 35, 1483-1494.

Graham, P. (1980) Moral development. In: Scientific Foundations of Developmental Psychiatry (ed. M. Rutter), pp. 339-353. London: William Heinemann.

Prnss, H. (1994) Psychiatry and the concept of evil. British Journal of Psychiatry, 165, 297-300.

RUTTER, M. (1983) A Measure of our Values. London: Quaker Home Service.

WAGNER, G. (1987) The Chocolate Conscience. London: Chatto \& Windus.

WEIR, K. \& DUVEEN, G. (1981) Further development and validation of the Prosocial Behaviour Questionnaire for use by teachers. Journal of Child Psychology and Psychiatry, 22, 357-375.

Professor Philip Graham, 27 St Albans Road, London NW5 1RG

(First received 7 April 1995, final revision 23 November 1995, accepted 4 January 1996) 